\title{
COVID-19 with repeated positive test results for SARS-CoV- 2 by PCR and then negative test results twice during intensive care: a case report
}

\author{
Masafumi Kanamoto ${ }^{*}$, Masaru Tobe, Tomonori Takazawa and Shigeru Saito
}

\begin{abstract}
Background: Determining the infectiousness of patients with coronavirus disease 2019 is crucial for patient management. Medical staff usually refer to the results of reverse transcription polymerase chain reaction tests in conjunction with clinical symptoms and computed tomographic images.

Case presentation: We report a case of a 62-year-old Japanese man who twice had positive and negative test results by polymerase chain reaction for severe acute respiratory syndrome coronavirus 2 over 48 days of hospitalization, including in intensive care. His respiratory symptoms and computed tomographic imaging findings consistent with coronavirus disease 2019 improved following initial intensive care, and the result of his polymerase chain reaction test became negative 3 days before discharge from the intensive care unit. However, 4 days after this first negative result, his polymerase chain reaction test result was positive again, and another 4 days later, he had a negative result once more. Eight days after the second polymerase chain reaction negative test result, the patient's test result again became positive. Finally, his polymerase chain reaction results were negative 43 days after his first hospitalization.

Conclusions: This case emphasizes the importance of repeat polymerase chain reaction testing and diagnosis based on multiple criteria, including clinical symptoms and computed tomographic imaging findings. Clinical staff should consider that a negative result by polymerase chain reaction does not necessarily certify complete coronavirus disease 2019 recovery.
\end{abstract}

Keywords: COVID-19, RT-PCR, Repeat positivity/negativity

\section{Introduction}

A number of cases of "unknown viral pneumonia" related to a market in Wuhan City, Hubei Province, China, were reported in December 2019. The novel severe acute respiratory syndrome coronavirus 2 (SARS-CoV-2) was identified, causing coronavirus disease 2019 (COVID19), which rapidly spread from China to other countries

\footnotetext{
* Correspondence: kanamoto@gunma-u.ac.jp

Department of Anesthesiology and Intensive Care Unit, Gunma University Hospital, 3-39-15 Showa, Maebashi, Gunma, Japan
}

all over the world. In the absence of specific therapeutic drugs or vaccines for COVID-19, it is essential to be able to detect the disease at an early stage and immediately isolate the infected person from the healthy population. According to the latest guidelines for the Diagnosis and Treatment of Pneumonitis Caused by 2019 Novel Coronavirus (Trial Version 6) published by the Chinese government, the diagnosis of COVID-19 requires testing respiratory or blood samples by reverse transcription polymerase chain reaction (RT-PCR) or gene sequencing

(c) The Author(s). 2020 Open Access This article is licensed under a Creative Commons Attribution 4.0 International License, which permits use, sharing, adaptation, distribution and reproduction in any medium or format, as long as you give appropriate credit to the original author(s) and the source, provide a link to the Creative Commons licence, and indicate if changes were made. The images or other third party material in this article are included in the article's Creative Commons licence, unless indicated otherwise in a credit line to the material. If material is not included in the article's Creative Commons licence and your intended use is not permitted by statutory regulation or exceeds the permitted use, you will need to obtain permission directly from the copyright holder. To view a copy of this licence, visit http://creativecommons.org/licenses/by/4.0/ The Creative Commons Public Domain Dedication waiver (http://creativecommons.org/publicdomain/zero/1.0/) applies to the data made available in this article, unless otherwise stated in a credit line to the data. 
and is considered the key indicator for hospitalization. Chest computed tomography (CT) reveals typical radiographic features in almost all patients with COVID-19, which include ground-glass opacities, multifocal patchy consolidation, and/or interstitial changes with a peripheral distribution. We now have a great deal of experience in treating patients with frequent changes from positive to negative PCR results, then back to positive and negative again. We therefore propose that accurate diagnosis and treatment of COVID-19 requires a comprehensive assessment that includes not only PCR results but also chest $\mathrm{CT}$ images.

\section{Case presentation}

A 62-year-old Japanese man without coexisting disease initially presented to our hospital with a persistent fever of $38.0^{\circ} \mathrm{C}$, dyspnea, and hypoxia after close contact with a coworker known to be infected with SARS-CoV-2. His oxygen saturation $\left(\mathrm{SpO}_{2}\right)$ on room air at the time of hospitalization was 94\%, and CT showed peripheral ground-glass opacities with interlobular septal thickening consistent with a "crazy paving pattern" strongly indicative of COVID-19 (Fig. 1). PCR results on the basis of a pharyngeal swab taken through the nostril were consistent with pneumonia and COVID-19. Because the patient's $\mathrm{SpO}_{2}$ decreased to $88 \% 25$ days after hospitalization despite $3 \mathrm{~L} /$ minute oxygen inhalation by face mask, he was transferred to the intensive care unit (ICU). He was intubated and put on a ventilator (Puritan Bennett 840,

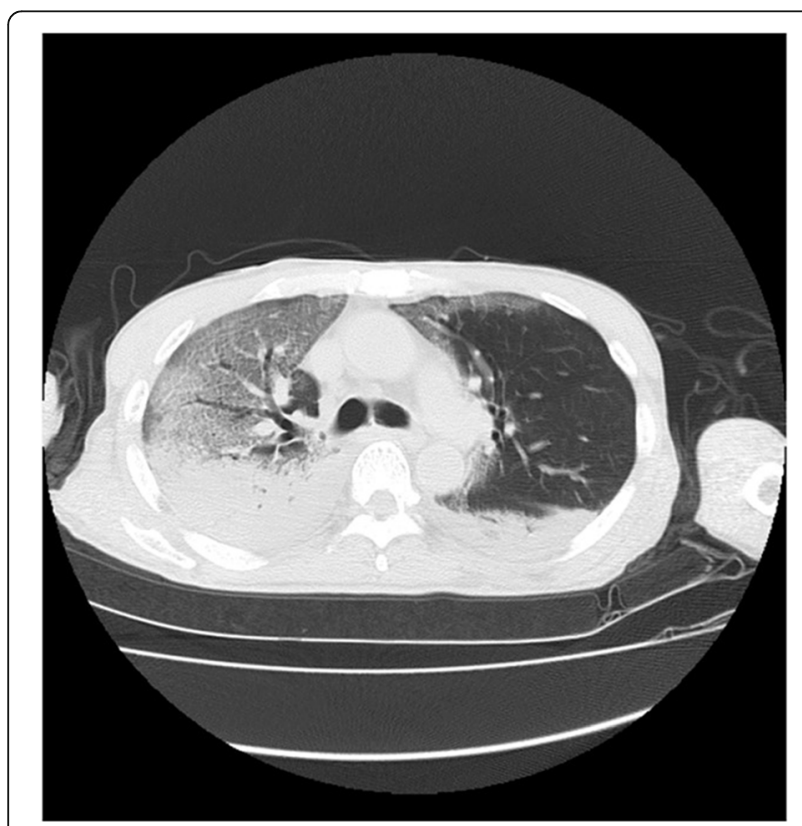

Fig. 1 Computed tomography of the chest demonstrating bilateral patchy ground-glass opacities with interlobular septal thickening consistent with the crazy paving pattern found in patients with coronavirus disease 2019
Medtronic, Tokyo, Japan; pressure control ventilation $[\mathrm{PCV}]$ mode, fraction of inspired oxygen $\left[\mathrm{FiO}_{2}\right], 0.5$, positive end-expiratory pressure [PEEP], $10 \mathrm{cmH}_{2} \mathrm{O}$; inspiratory pressure $[\mathrm{Pi}], 15 \mathrm{cmH}_{2} \mathrm{O}$; inspiratory time [Ti], $1.5 \mathrm{~s}$; frequency [f], 12 per minute). Other therapeutic procedures included administration of favipiravir, and, given concerns regarding pneumonia due to other pathogens, broad-spectrum antibiotic therapy using tazobactam/piperacillin and levofloxacin was initiated. The results of blood cultures and a respiratory viral panel were negative. The patient recovered without further incident and was transferred back to a convalescence ward in an affiliated hospital after confirmation of SARS-CoV-2 negativity by PCR. However, on the same day as the transfer, the patient complained of shortness of breath and dyspnea, and his respiration rate increased to 20 breaths/minute. His $\mathrm{SpO}_{2}$ decreased to $86 \%$ under $10 \mathrm{~L} /$ minute of $100 \%$ oxygen inhalation by face mask, and he was again intubated. At this time, the finding of PCR was once again positive for SARS-CoV-2, and the patient was readmitted to our hospital and transferred back to the ICU to restart respiratory care on a ventilator $\left(\mathrm{PCV}, \mathrm{FiO}_{2}, 0.4\right.$; $\mathrm{PEEP}, 8 \mathrm{cmH}_{2} \mathrm{O}$; $\mathrm{Pi}, 15 \mathrm{cmH}_{2} \mathrm{O}$; Ti, $1.5 \mathrm{~s}$; f, 12 per minute). Four days after readmission, his respiratory condition had improved, and his PCR results were again negative. Nine days after readmission, he was weaned off respirator care, extubated, and transferred to a COVID-19 ward in the same hospital. Over the remainder of his hospital course, the patient was treated by supportive measures and monitored for any worsening of respiratory function. Despite his respiratory condition not worsening, his PCR result again became positive 3 days after discharge from the ICU for the second time. At 8 and 11 days after this, his PCR results were negative once more. Following confirmation that his clinical condition and CT findings were stable, he was finally discharged from our hospital 54 days after his first admission.

\section{Discussion}

For successful management of the COVID-19 pandemic, diagnosis and discharge criteria have been discussed extensively with reference to the sensitivity and specificity of the clinical and virological status of patients before discharge. The PCR test is considered the gold standard for detecting infection and is widely used for diagnosis and public heath surveillance of disease prevalence. In this report, we describe a patient who repeatedly had positive test results and then negative and positive test results again several times during the course of his COVID-19 disease. Although there are several reports of PCR reverting to positivity following a negative result, twice repeating such a positive and negative course in one patient seems to be rare. Considering safe management for clinical staff and the patient him- or herself, 
the importance of repeat testing and screening based on clinical symptoms and exposure history cannot be overstated. PCR has emerged as the test of choice for detection of viral nucleic acids and the infectiousness of infected individuals. Although some reports in the literature emphasize the importance of PCR screening for early containment of the disease, the sensitivity of PCR tests has been shown to be anything but perfect. A study conducted in China found that almost 25\% of SARS-CoV-2-positive individuals had had a negative result in initial testing [1]. Another study reported that over $20 \%$ of infected individuals had positive test results on their third consecutive test after two initial negative results [2]. The sensitivity of PCR testing in several studies has been reported to be only 71$83 \%$, corresponding to a false-negative rate of up to $30 \%$ $[3,4]$. Considering this reported poor sensitivity of PCR for SARS-CoV-2, clinicians should be cautious when interpreting negative results of PCR testing in patients with clinical suspicion of COVID-19.

Our patient initially presented with fatigue progressing to fever, cough, and shortness of breath, symptoms that are most commonly attributable to COVID-19 pneumonia $[5,6]$. However, prior to his first discharge from the ICU, the patient was completely free of these symptoms, and his PCR result was negative. Because the CT images still showed some consolidation in the right upper and middle lung lobes, we consider it possible that the virus was in fact still present and that it moved out to the pharynx during transfer to a different hospital. Although we considered that some kind of coexisting bacterial pneumonia could be the main reason for the patient's retarded recovery as seen by $\mathrm{CT}$, these $\mathrm{CT}$ images may in fact have more importance for evaluating COVID-19 disease. A case report stated that CT imaging should be an integral component of screening for COVID-19 in preoperative patients [7]. Typical CT findings include consolidation, vascular enhancement, air bronchus sign, and bilateral peripheral ground-glass opacities with interlobular septal thickening consistent with a "crazy paving pattern" [8]. In our patient's case, these features were apparent at the initial admission. However, such findings were not apparent at the second admission to the ICU. These CT findings are clearly not specific for COVID-19 and may also be present in other viral or bacterial pneumonias. However, increasing numbers of clinical reports are emphasizing the efficacy of CT imaging for treating patients with this viral disease, and several clinical surveys have shown that CT imaging can enhance the accuracy of COVID-19 diagnosis over and above PCR alone [3, 9]. These recent reports support the notion that recovery from SARS-CoV-2 infection and the criteria for deciding on hospital discharge criteria should be based not only on the PCR results but also on assessment of CT images and clinical symptoms.

\section{Conclusions}

First, a negative PCR test result confirms neither recovery from COVID-19 nor that the patient is no longer infectious. Considering the poor sensitivity of PCR, repeat testing is essential to identifying SARS-CoV-2-positive individuals at initial diagnosis. A second important conclusion is that isolation and treatment practices should be guided by a combination of testing, symptomology, and radiologic evidence at the time of discharge and should not rely solely on PCR. Careful consideration based on these multiple parameters may prevent premature discharge of the "presumed negative" patients and thus also prevent unexpected exposure of healthcare workers and the population at large.

\section{Acknowledgements \\ The authors thank NAI (Tokyo, Japan) for assistance with manuscript preparation in English.}

\section{Authors' contributions}

MK was mainly to manage the patient, reviewed the patients' records and wrote the manuscript. MT, TT and SS were involved in the process of diagnosis and management. All authors read and approved the final manuscript.

\section{Funding}

The authors have no financial relationships to disclose.

\section{Availability of data and materials}

Please contact the author for data requests.

\section{Ethics approval and consent to participate}

The patient provided written informed consent to participate in this case report, which was approved by the Ethics Committee of Gunma University Hospital.

\section{Consent for publication}

Written informed consent was obtained from the patient for publication of this case report and any accompanying images. A copy of the written consent is available for review by the Editor-in-Chief of this journal.

\section{Competing interests}

The authors declare that they have no competing interests.

Received: 12 July 2020 Accepted: 14 September 2020

Published online: 07 October 2020

\section{References}

1. Li Y, Yao L, Li J, et al. Stability issues of RT-PCR testing of SARS-CoV-2 for hospitalized patients clinically diagnosed with COVID-19. J Med Virol. 2020; 92(7):903-8.

2. Xiao AT, Tong YX, Zhang S. False-negative of RT-PCR and prolonged nucleic acid conversion in COVID-19: rather than recurrence. J Med Virol. 2020; 92(10):1755-6.

3. Fang $Y$, Zhang $H$, Xie J, et al. Sensitivity of chest CT for COVID-19: comparison to RT-PCR. Radiology. 2020;296(2):E115-7.

4. Long $\mathrm{C}, \mathrm{Xu} \mathrm{H}$, Shen $\mathrm{Q}$, et al. Diagnosis of the coronavirus disease (COVID19): rRT-PCR or CT? Eur J Radiol. 2020;126:108961.

5. Chen T, Dai Z, Mo P, et al. Clinical characteristics and outcomes of older patients with coronavirus disease 2019 (COVID-19) in Wuhan, China (2019): a single-centered, retrospective study. J Gerontol A Biol Sci Med Sci. 2020; 75(9):1788-95.

6. Fu L, Wang B, Yuan T, et al. Clinical characteristics of coronavirus disease 2019 (COVID-19) in China: a systematic review and meta-analysis. J Infect. 2020;80(6):656-65 
7. Fisher B, Seese L, Sultan I, Kilic A. The importance of repeat testing in detecting coronavirus disease 2019 (COVID-19) in a coronary artery bypass grafting patient. J Card Surg. 2020;35(6):1342-4.

8. Dai H, Zhang X, Xia J, et al. High-resolution Chest $\mathrm{CT}$ features and clinical characteristics of patients infected with COVID-19 in Jiangsu, China. Int J Infect Dis. 2020;95:106-12.

9. Feng H, Liu Y, Lv M, Zhong J. A case report of COVID-19 with false negative RT-PCR test: necessity of chest CT. Jpn J Radiol. 2020;38(5):409-10.

\section{Publisher's Note}

Springer Nature remains neutral with regard to jurisdictional claims in published maps and institutional affiliations.

Ready to submit your research? Choose BMC and benefit from:

- fast, convenient online submission

- thorough peer review by experienced researchers in your field

- rapid publication on acceptance

- support for research data, including large and complex data types

- gold Open Access which fosters wider collaboration and increased citations

- maximum visibility for your research: over $100 \mathrm{M}$ website views per year

At $\mathrm{BMC}$, research is always in progress.

Learn more biomedcentral.com/submissions 